European journal of American studies

Special Issue: Contagion and Conviction: Rumor and Gossip in American Culture

\title{
Contagion and Conviction: Rumor and Gossip in American Culture
}

Pierre-Héli Monot and Florian Zappe

\section{(2) OpenEdition \\ Journals}

Electronic version

URL: https://journals.openedition.org/ejas/16356

DOI: $10.4000 /$ ejas. 16356

ISSN: 1991-9336

Publisher

European Association for American Studies

Electronic reference

Pierre-Héli Monot and Florian Zappe, "Contagion and Conviction: Rumor and Gossip in American Culture", European journal of American studies [Online], 15-4 | 2020, Online since 17 December 2020, connection on 09 July 2021. URL: http://journals.openedition.org/ejas/16356 ; DOI: https://doi.org/ 10.4000/ejas. 16356

This text was automatically generated on 8 July 2021.

Creative Commons License 


\title{
Contagion and Conviction: Rumor and Gossip in American Culture
}

\author{
Pierre-Héli Monot and Florian Zappe
}

1 In recent years, scholarly and political discourses have increasingly tended to rhetorically conflate the circulation of information and the circulation of viral pathogens. Rumor and gossip are routinely taken to be "contagious" (Franks and Attia) and the massive circulation of information in the public sphere is said to be akin to "viral events" (Nahon and Hemsley). Trapped within the precarious logic of absolute metaphors (cf. Blumenberg 14), scholarly and political discourses have, in turn, advocated therapeutic measures that seem warranted by their rhetorical underpinnings only: the Body Politic, once infected by gossip and rumor, is to be healed by a talking cure (via neoliberal "pedagogy") or, for more severe cases, by a diet of political truth in the public sphere (via laws regulating the circulation of "fake news" and the formation of discursive "echo chambers"). In turn, these metaphors have had a certain influence on the public styles of major global institutions; in 2020, calls to "flatten the infodemic curve" were addressed to "everyone" (World Health Organization).

2 While conspiracy theories, political lies, and disinformation are very serious problems for Western democracies, the viral metaphors that are used to describe them have also overshadowed many of the social uses of rumor and gossip. Rumor and gossip are fundamental to the formation of political convictions. They also play a vital role in the elaboration of political rationality by the public, and they secure social bonds among and between different social groups. There are also abundant historical reasons not to discard rumor and gossip as objects of inquiry: the American public sphere has always proved to be fertile ground for both.

3 Although these types of communication have always been ubiquitous across all segments of U.S. society, they have only occasionally come to the attention of scholars of American culture and politics in any kind of systematic way (see Goodman and Aaron Ben-Ze'ei 1994; Warner 2002; Besnier 2009; Feeley and Frost 2014; Adkins 2017). Furthermore, as established notions of the American public sphere are currently 
undergoing wide-ranging changes, the dynamics of rumor and gossip have to be reassessed. In the present historical context, the distinction between hearsay and substantiated fact increasingly appears to be faltering, and conspiracy theories are slowly overstepping the confines of obscure counterpublics and taking center stage in cultural, social and political debates. Against this backdrop, a thorough investigation of the role of gossip and rumor in the American public sphere seems to be more than necessary.

4 This special issue attempts to make a concerted contribution to this endeavor. It is conceptually based on the premise that gossip and rumor are never neutral. In fact, in his canonical study Weapons of the Weak: Everyday Forms of Peasant Resistance (1985), anthropologist and political scientist James C. Scott notes that gossip is never "disinterested" when it circulates in the social realm: "it is a partisan effort (by class, faction, family) to advance its claims and interests against those of others" (282). Its strategic uses can be comparatively mundane or distinctly expedient, yet it seems evident that the "usefulness of gossiping to individuals is that it helps our everyday life (and also our Darwinian fitness) by telling us whom to trust and cooperate with, and which free-riders to avoid" (Boehm 254). This basic anthropological proposition has far-reaching political implications: being "a partisan effort" by definition, gossip offers different political and cultural possibilities to distinct social groups. It can serve emancipatory purposes when it is used as a form of subaltern resistance by segments of society that are otherwise excluded from hegemonic public discourse, as it allows the emergence of subversive, alternative or insurgent counterpublics. "As a form of resistance," Scott notes, "gossip is a kind of democratic 'voice' in conditions where power and possible repression make open acts of disrespect dangerous" (282). Socially and economically powerful groups, of course, are free to openly show their contempt for the "undeserving poor." For the latter, however, gossip makes the expression of contentious opinions, of contempt, of disapproval possible while minimizing the risks of identification and reprisal (282). On the other hand, hegemonial structures have frequently used forms of gossip (malicious gossip, character assassination, etc.) to frame and discredit the reputation of publics and counterpublics with repressive or disciplinary intent.

The inherent ambiguity in the nature of gossip and rumor raises a number of fundamental questions that will, and should, be addressed from a broad scholarly perspective: How have rumors helped to constitute "publics" and "counterpublics" in American history? How has gossip been employed as an either top-down or bottom-up discourse by various segments of society? Why has gossip itself been the object of such academic discredit, given its status as one of the preeminent types of communication in American public discourse?

6 We raise these questions with a certain sense of urgency. Indeed, while Scott's classic account of gossip implied a strict distinction between subaltern and socially dominant uses of gossip, the great transformations of the American public sphere we are currently witnessing have started to blur these coordinates. Donald Trump's appropriation of gossip as a historically defined marker of subalternity has been but the most glaring aspect of this phenomenon as he effectively managed to use subaltern rhetoric from a position of massive institutional power. Gossip and rumor have consistently been instrumental in his political career, and his constant use of these styles has seemingly upended the narrative of the public/counterpublic dichotomy. He 
has hijacked a subaltern mode of communication and reaffirmed the social and economic imbalance of the power structure. It is arguably Trump's appropriation of gossip as a discursive mode, rather than the general populist tenor of his rhetoric, that has made the explicit reformulation of "the public sphere" as "the People" possible.

7 In light of the recent resurgence of rumor and gossip as categories of discourse in American culture and, via some rare disciplinary advances, in American Studies, this special issue gathers essays that analyze and theorize these categories in their various historical formations and functions.

This discussion has to extend beyond disciplinary boundaries. We have therefore convened a diverse group of international scholars from the fields of American literary and cultural studies, as well as from the fields of history, media and communication studies, to contribute to this debate. In so doing, we follow calls to implement concrete interdisciplinary approaches to effectively overcome "the quantitative-qualitative divide" in American Studies (Vormann 189), rather than just verbally invoking the purported potentials of scholarly collaboration beyond disciplinary divides.

The papers we have selected address the whole scope of American Studies, including discussions of canonical and non-canonical literary uses of gossip and rumor, a study of the viral propagation of gender-marked gossip in the American public sphere, an essay on the function of gossip in the historical formation of American Studies as a discipline, and essays on the transnational, Euro-American circulation of gossip. By employing a functionalist understanding of gossip, rather than focusing on its inherent rhetorical or epistemological properties, we suggest that gossip engages directly with the central questions of our common scholarly methods and interests. We hence hope that providing a selection of innovative, theoretically and historically informed essays on the subject will substantially contribute to the current epistemological reflections at play in the field.

10 The issue opens with a prologue: Liam Kennedy's “'This is not America': States of Emergency in Europe" underscores the implicit nature of the central political transformations that have occurred since 2016. He emphasizes the overlap between the various crises that have recently hit Euro-American relations. The COVID-19 pandemic, the protests in solidarity with the victims of racist crimes, and the return of American isolationism as a mainstay of the Trump presidency, have all contributed to European disinvestment from the fantasy of America as a liberal and redemptive power. They have also failed to elicit coherent responses, indicating "a suspension of 'normal' social relations and widespread uncertainty about what will constitute a 'new normal."'

In "Provocative Talk in Local American Civic Life," Samuel McCormick analyzes a local political debate in order to advance our understanding of the use of chatter, gossip, and idle talk for purposes of provocation, antagonism, and radical dissensus in local American civic life. Starting with a detailed qualitative case study, this essay works inductively from the specific rhetorical contours of a local public debate toward a broader philosophical perspective on the communicative practice of everyday talk, suggesting that there is always something extraordinary about ordinary civic discussion and debate.

12 The issue continues with an essay by Katrin Horn entitled "The Public Gossip of Town Topics: The Journal of Society (1885-1937)," which analyzes the gossip column "Saunterings" in the magazine Town Topics, published in New York between 1885 and 1937. This essay focuses on the ways in which gossip (originally a private form of 
communication) has been adopted to create the feeling of intimate communication in the public sphere in the larger context of early celebrity culture.

In his essay "Is All Discourse Official? On the Poetics of Gifting and Gossiping," PierreHéli Monot draws on Marcel Mauss' analysis of gift economies to discuss "gossiping" as a crucial hermeneutic problem in literary theory. While canonical novels such as John Steinbeck's The Grapes of Wrath stage the political uses of gossiping, literary theory since Claude Lévi-Strauss has underestimated the massive consequences gossiping ought to have for critical practices.

Florian Zappe's essay 'In the Shadow of the 'Indeterminate Speech-Act:' The Populist Politics of Rumor in Fritz Lang's Early Sound Films" analyzes Lang's first sound film $M$ (Germany, 1931) and his first Hollywood production Fury (1936), claiming that they not only mark two important steps in the director's transnational career but also a fundamental shift in the politics of his cinema. Drawing on Gilles Deleuze's definition of rumor as an "indeterminate speech-act," Zappe argues that Lang's cinematic treatment of the toxic efficacy of the dynamics of rumor provides a gateway to his integration into American liberalism.

In "Secrecy, Suspicion, Exposure: Negotiating Authority Structures in a Settler Colonial Society as Depicted in Walter Van Tilburg Clark's The Ox-Bow Incident," Mare Paryż discusses Van Tilburg Clark's classic Western novel as a narrative about a fundamental step towards the socio-cultural modernization of societies of the Far West. Paryż analyzes the respective functions of secrecy, gossip, suspicion, and exposure in this process.

16 Sebastian Jobs offers a historian's perspective on rumors, discussing their value as historical sources. Arguing that rumors should be treated as historical events that push the boundaries of "doing history" as a scholarly task, Jobs analyzes the archival status of rumors and the terminology that is used to describe them. He discusses the fundamental question of what effects uncertainty as a research topic has on the process of historiography itself, and he concludes with a reflection on the "speechlessness" that results from the failure of the historian's usual terminology when dealing with rumors as historical material.

Maria Verena Peters's essay addresses the way communication amongst women is stigmatized as gossip, especially during political crises which engage questions of gender equality. In "From the Whisper Network to \#MeToo-Framing Gender, Gossip and Sexual Harassment," she questions the perceived demise of this narrative in the wake of the \#MeToo movement. While "whisper networks" have become more visible and public on social media platforms, the way in which women's speech and testimony are discredited has not fundamentally changed.

\section{BIBLIOGRAPHY}

Adkins, Karen. Gossip, Epistemology, and Power: Knowledge Underground. Palgrave Macmillan, 2017. 
Besnier, Nico. Gossip and the Everyday Production of Politics. U of Hawaii P, 2009.

Blumenberg, Hans. Paradigms for a Metaphorology. Signale, 2010.

Boehm, Christopher. "Gossip and Reputation in Small-Scale Societies." The Oxford Handbook of Gossip and Reputation, edited by Francesca Giardini and Rafael Wittek. Oxford UP, 2019, pp. 253-274.

Feeley, Kathleen, and Jennifer Frost. When Private Talk Goes Public: Gossip in American History. Palgrave Macmillan, 2014.

Franks, Bradley, and Sharon Attia. "Rumours and Gossip as Genres of Communication." The Social Psychology of Communication, edited by Derek Hook, Bradley Franks and Martin W. Bauer.

Palgrave, 2011, pp. 169-186.

Goodman, Robert, F. and Aaron Ben-Ze'ei (Ed.). Good Gossip. UP of Kansas, 1994.

Nahon, Karine and Jeff Hemsley. Going Viral. Polity, 2013.

Vormann, Boris. "Greater Than the Sum of Its Parts: American Studies as Interdisciplinary Area Studies." Projecting American Studies. Essays on Theory, Method, and Practice, edited by Frank Kelleter and Alexander Starre. Winter, 2018, pp. 183-196.

Warner, Michael. Publics and Counterpublics. Zone Books, 2002.

World Health Organization. "Let's Flatten the Infodemic Curve", 2020, https://www.who.int/ news-room/spotlight/let-s-flatten-the-infodemic-curve. Accessed 3 Dec. 2020.

\section{AUTHORS}

\section{PIERRE-HÉLI MONOT}

Pierre-Héli Monot is Professor of American Studies (Political Theory, Aesthetics, and Public Humanities) at the Ludwig-Maximilians-Universität of Munich, Germany. He is the Principal Investigator of the ERC Starting Grant research project The Arts of Autonomy: Pamphleteering, Popular Philology, and the Public Sphere, 1988-2018. His first book, entitled Mensch als Methode: allgemeine Hermeneutik und partielle Demokratie (Heidelberg, 2016) discusses the emergence of romantic hermeneutics, the abolition of slavery in the United States, and the formation of the modern literary field. He has held Visiting Fellowships at Harvard University, Brown University, and King's College London.

\section{FLORIAN ZAPPE}

Florian Zappe is an Assistant Professor of American Studies at the Georg-August-University Göttingen, Germany. He is the author of books on William S. Burroughs ('Control Machines' und 'Dispositive'-Eine foucaultsche Analyse der Machtstrukturen im Romanwerk von William S. Burroughs zwischen 1959 und 1968, Peter Lang, 2008) and Kathy Acker (Das Zwischen schreiben-Transgression und avantgardistisches Erbe bei Kathy Acker, transcript, 2013), as well as the co-editor of the essay collections Spaces and Fictions of the Weird and the Fantastic: Ecologies, Geographies, Oddities (Palgrave, 2019), Surveillance/Society/Culture (Peter Lang, 2020) and The American Weird: Concept \& Medium (Bloomsbury, 2020). In addition to that, he has published widely on literary and visual culture. 